\title{
INCREASED OSTEOPOROTIC FRACTURES' RISK IN ELDERLY PATIENTS WITH LOWER SODIUM LEVELS
}

\author{
R.A. Trifanescu ${ }^{1,2}$, M. Carsote ${ }^{1,2}$, D. Soare1, C. Poiana ${ }^{1,2}$ \\ ${ }^{1}$ Dept. of Endocrinology, "Carol Davila" Univ. of Medicine and Pharmacy, \\ 2 "C.I. Parhon" National Institute of Endocrinology, Bucharest, Romania
}

BACKGROUND: Low serum sodium levels were associated both in experimental studies and in clinical practice with increased prevalence of osteoporosis, due to decreased bone mineralization and increased osteoclastic activity. On the other hand, hyponatremia - independent of osteoporosis - is associated with fractures' occurrence.

OBJECTIVES: to assess the relationship between serum sodium levels and osteoporotic fractures.

\section{PATIENTS and METHODS:}

$>160$ patients $(7 \mathrm{M} / 153 \mathrm{~F})$, aged $62.2 \pm 11$ years were retrospectively assessed.

> DXA measurement was performed in 133 patients. In all the other 27 patients, DXA was not considered mandatory due to presence of osteoporotic fractures.

$>$ serum natremia was measured in all patients.

\section{RESULTS:}

41 out of 160 patients $(25.6 \%)$ showed various types of osteoporotic fractures.

Table 1. Serum sodium levels according to osteoporotic fractures' presence

\begin{tabular}{cccc}
\hline & $\begin{array}{c}\text { Patients with osteoporotic } \\
\text { fractures' }\end{array}$ & $\begin{array}{c}\text { Patients without } \\
\text { osteoporotic fractures }\end{array}$ & p \\
\hline $\mathbf{N}(\%)$ & $41(25.6 \%)$ & $119(74.4 \%)$ & - \\
Age (years) & $71.6 \pm 9.5$ & $58.9 \pm 11$ & $<0.001$ \\
Serum $\mathrm{Na}^{+}(\mathrm{mmol} / \mathrm{L})$ & $139.2 \pm 3.1$ & $141.1 \pm 5.32$ & 0.01 \\
Prevalence of hyponatremia N(\%) & $4 / 41(9.7 \%)$ & $6 / 119(5.04 \%)$ & 0.28 \\
\hline
\end{tabular}

Figure 1. Types of fractures in studied patients $(n=41)$

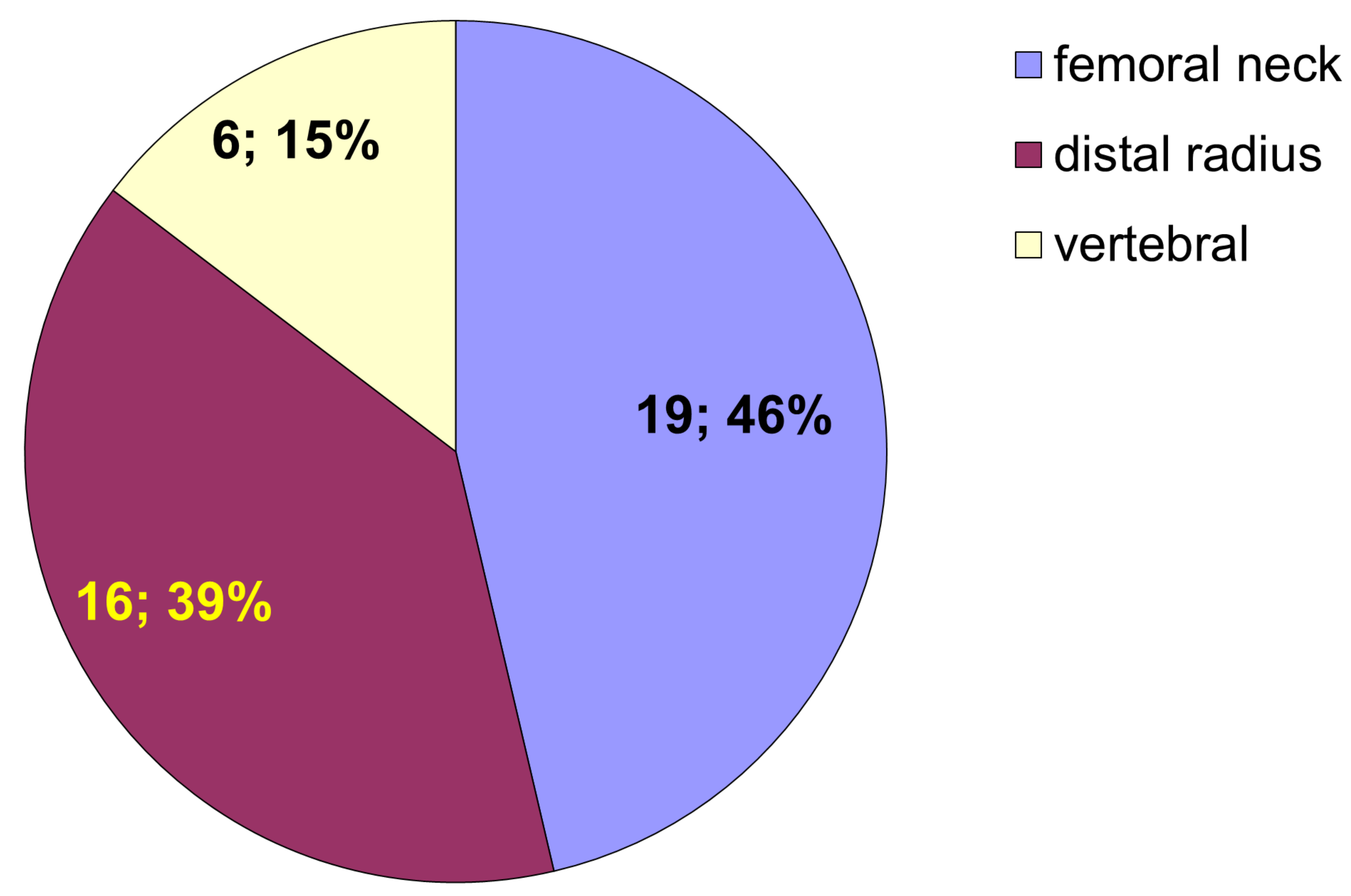

Figure 2. Bone mineral density (BMD) in patients with DXA assessment $(n=133)$

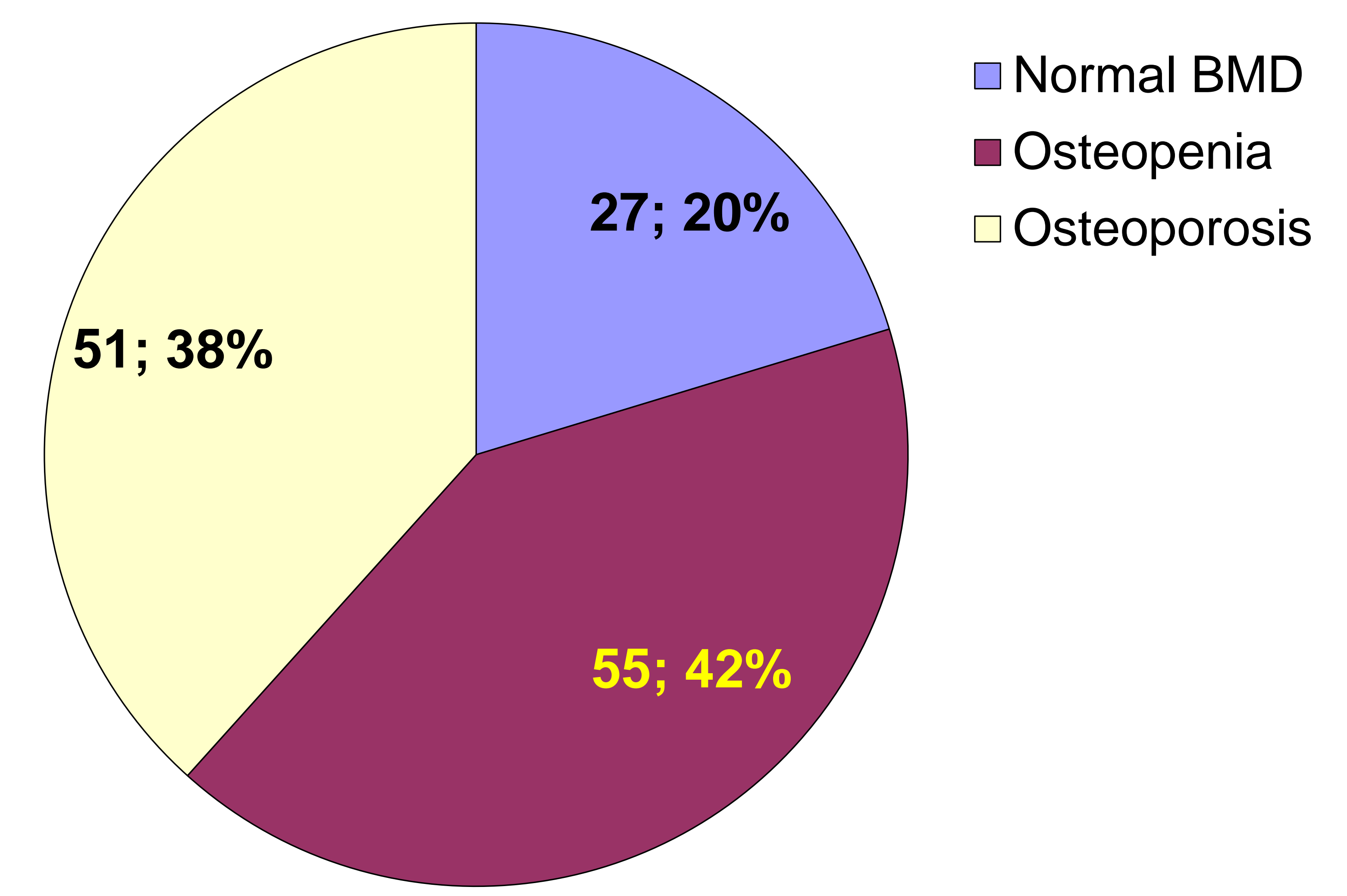

Prevalence of hyponatremia tends to be lower in patients with normal bone mineral density and osteopenia $(1 / 27-3.7 \%$ and $2 / 55-3.6 \%)$ than in patients with osteoporosis $(4 / 51-7.8 \%)$.

CONCLUSION: we suggest measurement of sodium serum levels in elderly people at risk of osteoporotic fractures. 